\title{
Stylized Facts on the Organization of Small Business Partnerships
}

\author{
Emilio Espino, Julian Kozlowski, and Цuan M. Sánchez
}

\begin{abstract}
The authors study the internal organization of small business partnerships and focus on the number of owners and ownership structure and the dynamics of these variables. They find that partnerships tend to have a small number of owners with equal distribution of ownership shares. Moreover, while partnerships with equally distributed shares tend to keep this distribution constant, those with unequally distributed shares tend to move toward more equal distribution over time. The authors highlight that these facts are in line with the theory of private information in small business partnerships proposed by Espino, Kozlowski, and Sánchez (2014). (JEL D82, D86, D92, G32)
\end{abstract}

Federal Reserve Bank of St. Louis Review, Fourth Quarter 2016, 98(4), pp. 297-310.

http://dx.doi.org/10.20955/r.2016.297-310

\section{INTRODUCTION}

Small businesses in some sectors (e.g., service) are frequently organized as partnerships. These businesses are formed by a few partners, who contribute money, property, labor, and/ or skills and receive a share of ownership. In general, they have very limited access to credit and most of their resources for investment are raised internally. Although partnerships are important in the economy, not much is known about their organization. A recent article by Espino, Kozlowski, and Sánchez (2014; EKS hereafter) attempts to fill this gap by presenting a theory of small business partnerships. They study incentive problems between partners and how these problems affect investment and ownership of small business partnerships. In this article, we analyze empirical evidence on small business partnerships to evaluate the main predictions of EKS's theory.

The theory has three main features that make it suitable for studying small business partnerships. First, it assumes each firm is owned by two partners. This assumption is appealing because, as noted below, the great majority of partnerships have only two owners. Second, firms use physical capital (e.g., equipment, software, and structures) to generate income, and all investment must be obtained from retained earnings (i.e., there is no access to external

Emilio Espino is a professor at the Universidad Torcuato Di Tella, Julian Kozlowski is a PhD student at New York University, and Juan M. Sánchez is a research officer at the Federal Reserve Bank of St. Louis.

(C) 2016, Federal Reserve Bank of St. Louis. The views expressed in this article are those of the author(s) and do not necessarily reflect the views of the Federal Reserve System, the Board of Governors, or the regional Federal Reserve Banks. Articles may be reprinted, reproduced, published, distributed, displayed, and transmitted in their entirety if copyright notice, author name(s), and full citation are included. Abstracts, synopses, and other derivative works may be made only with prior written permission of the Federal Reserve Bank of St. Louis. 


\section{Espino, Kozlowski, Sánchez}

financing). Old and recent papers have found that access to external financing is limited and small businesses rely heavily on internal resources (Butters and Lintner, 1945; Hubbard, 1998; and Carpenter and Petersen, 2002). Butters and Lintner (1945), in particular, study the early histories of several industries and conclude that most small firms finance their growth almost exclusively through retained earnings. Last, incentive problems arise because partners desire to use the partnership, which is their only source of income, as an insurance mechanism against fluctuating funding needs, for example, for extreme and unexpected health problems. Interestingly, anecdotal evidence supports this type of shock. 1

Why do individuals form business partnerships? There are two advantages and one disadvantage. The first advantage is to raise funds. In an economy with limited access to credit, two persons may form a partnership to raise enough capital to run the firm at optimal scale. The second advantage is risk-sharing. If the partners have idiosyncratic risk, a partnership may be useful for pooling risk. The main disadvantage is incentive problems. What is best for the partnership is not necessarily best for the individual owners. Partners may have the incentive to misrepresent the cost of their effort or their needs to extract resources from the other partner(s). Incentive problems can distort the optimal investment plan for the partnership.

EKS (2014) study the optimal organization of partnerships. In their model, partnerships are ventures formed with capital contributions from two members who receive ownership shares. Over time, the amount of profits reinvested in the firm, instead of being paid out to the partners, depends on the partners' liquidity needs. When liquidity needs are publicly known by both partners, the ownership structure does not change over time. However, when liquidity needs are private information, each partner may have the incentive to exaggerate his needs to withdraw more resources out of the partnership. Hence, changes in the ownership structure might be used to provide the incentive not to cheat; that is, a partner who reports high liquidity needs and receives a higher payout this period will have his ownership share reduced. Additionally, because investment decreases when a partner reports high liquidity needs, misreporting reduces future payouts for all partners-especially those with large ownership shares. As a consequence, there exists a threshold of ownership such that when ownership shares are large enough, the incentive to misreport vanishes.

The EKS theory has several predictions that we test. First, the theory predicts that having all partners (owners) with large ownership shares reduces the incentive to cheat (since cheating would distort investment). Thus, the first testable prediction is that partnerships should have a small number of owners, all with large ownership shares. Second, the theory predicts that when the ownership structure does not provide enough incentive to discourage cheating, the ownership shares will fluctuate to provide the incentive (as described above). Thus, the second testable prediction is that fluctuations in ownership shares are more frequent in partnerships with unequally distributed ownership shares (i.e., with ownership structures more likely to generate incentive problems). Last, the third testable prediction is that unequal partnerships subject to private information will converge over time to equal ownership or sole proprietorship. In general, this prediction means that the number of owners of the partnership will decline over time to provide the incentive not to cheat. This transition occurs because if there are too many owners, those with small shares will have a stronger incentive to cheat. For 
instance, with four owners, even equal shares of ownership (25 percent each) might not provide enough incentive to deter cheating. In such a case, the provision of incentives dictates that the shares of some will converge to zero.

In this article, we find several facts in line with EKS's testable predictions. First, most start-ups have only a few owners: About 50 percent have one, 30 percent have two, and only 20 percent have three or more. This fact is robust across the different data sources and countries considered. Second, firms usually start by splitting ownership shares equally across partners. About 70 percent of two-owner start-ups have approximately equal shares (i.e., about 50 percent per owner) and 30 percent of three-owner start-ups have approximately equal shares (i.e., about 33 percent per owner). As the number of owners increases, the share of partnerships with equally distributed shares decreases. Third, start-ups with equally distributed shares change their ownership structure less frequently than those with unequally distributed shares. Fourth, the probability of equally shared ownership changes during the life cycle of partnerships. In particular, for privately owned firms, the probability increases with firm age significantly more for non-family-owned firms than for family-owned firms. Last, in countries with access to better monitoring technologies or better corporate transparency, which can potentially alleviate informational frictions, the number of owners in the partnership decreases more slowly with firm age.

\section{RELATED LITERATURE}

Models of business partnerships focus on the formation of partnerships and use static models. Some papers study the choice between partnerships and corporations (e.g., Kaya and Vereshchagina, 2014, and Levin and Tadelis, 2005). Other papers study how the initial ownership structure affects the provision of incentives (e.g., Bolton and Von Thadden, 1998, and Vereshchagina, 2013). Many papers use data to check the predictions of these private information models and provide evidence in favor of the main features of the EKS model.

Lang and Gordon (1995), for example, analyze data from law partnerships and find significant evidence that firms adopt compensation mechanisms that trade off incentives for risk spreading. Similarly, Gaynor and Gertler (1995) analyze data on partnerships of medical group practices and provide evidence that partnerships form to spread risk due to uncertainty. They show the trade-off between risk sharing and moral hazard in partnerships. Gaynor and Gertler (1995) argue that compensation arrangements with greater degrees of revenue sharing significantly reduce physician effort. Both papers consider a simple static model and have no predictions about the dynamics and investment in partnerships, which is the focus of EKS.

Encinosa, Gaynor, and Rebitzer (2007) use a dataset with information about medical practices and report that the fraction of practices with equal shares falls as the number of owners increases-facts in line with the EKS theory: 54.2 percent of practices with three to five physicians, 42 percent of practices with six to seven physicians, and roughly 20 to 30 percent on average of larger practices have equal ownership shares.

The rest of the article is organized as follows. Section 3 describes partnerships at the aggregate level and the datasets used in the empirical analysis. Section 4 analyzes the cross section 
Table 1

Net Income by Type of Business and Industry (percent)

\begin{tabular}{lccc} 
& Sole proprietorships & Partnerships & Corporations \\
\hline All & 15 & 27 & 58 \\
\hline Legal services & 23 & 65 & 11 \\
\hline Professional services & 39 & 42 & 19 \\
\hline Accounting services & 26 & 59 & 15 \\
\hline Agriculture & 13 & 58 & 29 \\
\hline Mining & 3 & 52 & 45 \\
\hline Finance and insurance & 5 & 55 & 40 \\
\hline Consulting services & 56 & 19 & 25 \\
\hline
\end{tabular}

NOTE: Data are for 2008.

SOURCE: Internal Revenue Service.

of partnerships, while Section 5 shows the dynamics of the ownership structure with firm age. Section 6 studies the role of private information. Section 7 concludes the article.

\section{THE DATA ON PARTNERSHIPS}

We start by studying the types of U.S. businesses. A firm's legal status can be a sole proprietorship, a partnership, or a corporation. The optimal decision varies across sectors, but partnerships account for 27 percent of the net income generated by all U.S. businesses. Table 1 shows that in some industries, such as legal services, partnerships can account for as much as 65 percent of net income. Overall, in industries where the optimal scale is a small firm, businesses tend to be partnerships. In the rest of the article, we focus on the organization of small private firms and partnerships.

\subsection{Firm-Level Datasets}

To analyze the ownership structure of small businesses, we complement empirical evidence from three alternative firm-level datasets: the Kauffman Firm Survey (KFS), the 2003 Survey of Small Business Finances (SSBF), and the CAF Survey (CAF).

The KFS panel dataset has followed 4,928 businesses that started in 2004 and followed them for four years. This dataset is interesting because it studies small businesses when they start, so restricting our sample to small businesses does not necessarily imply that unsuccessful businesses are oversampled. Another key advantage of this dataset is that it follows businesses over time, allowing us to study partnership dynamics.

The SSBF dataset is interesting because it is a large sample with potentially widely varying firm types and ages (e.g., start-ups as well as 50-year-old firms) and it contains many questions about the firms (e.g., "Is the firm a family firm?"). We use this information to compare ownership across firms of different ages and ownership types (family vs. private). 
Table 2

Ownership Structure of Small Businesses

\begin{tabular}{|c|c|c|c|}
\hline & KFS & SSBF & CAF \\
\hline \multicolumn{4}{|l|}{ 1-Owner business } \\
\hline$\%$ of total & 60.44 & 47.59 & 59.81 \\
\hline$\%$ with equal shares & 100 & 100 & 100 \\
\hline \multicolumn{4}{|l|}{ 2-Owner business } \\
\hline$\%$ of total & 27.12 & 30.46 & 26.95 \\
\hline$\%$ with equal shares & 71.21 & 70.30 & \\
\hline \multicolumn{4}{|l|}{ 3-Owner business } \\
\hline$\%$ of total & 6.30 & 7.53 & 7.09 \\
\hline$\%$ with equal shares & 37.74 & 26.39 & \\
\hline Total number of observations & 4,928 & 21,200 & 423 \\
\hline
\end{tabular}

Finally, the CAF dataset is, a priori, very different from the other two because the survey interviewed individuals in many countries in Latin America and the United States. We analyze the responses of households that reported owning a business. Information about the business is limited, however. For instance, there is no information about ownership structure. Nevertheless, the data allow us to compare the behavior of firms in different countries exposed to different degrees of private information.

\section{CROSS SECTION OF PARTNERSHIP STRUCTURES}

In this section we study the number of owners and the distribution of shares in a cross section of partnerships.

\subsection{How Many Owners Does a Partnership Have?}

The first column of Table 2 shows that, according to the KFS, most starting businesses have very few partners: 60 percent have only one owner, almost 30 percent have two owners, and about 6 percent have three owners. It is interesting that most of the partnerships have at most three partners, because the theory presented in Section 2 predicts that partners with small shares will have more incentive to cheat and misreport liquidity needs. Therefore, it seems optimal to have a small number of owners to prevent problems related to private information.

In the KFS, the distribution of ownership shares across partners is also very peculiar. We define "equal shares," that is, in the too-big-to-cheat region, as two-owner and three-owner firms having shares lying in $[50 \times 0.95,50 \times 1.05]$ and $[33 \times 0.95,33 \times 1.05]$, respectively. More 
than 70 percent of two-owner partnerships have approximately equally distributed ownership shares. This pattern is interesting because theory predicts that the incidence of private information tends to be minimized with two-owner partnerships. In a three-owner partnership, it is difficult for each owner to be too big to cheat. Consistent with EKS (2014), only a few threeowner partnerships, although still a significant number, have approximately equally distributed ownership shares.

Next, we describe small U.S. businesses in the SSBF. Table 2 shows that, despite large differences across surveys, the fractions of firms in the SSBF (second column) with one, two, or three owners is similar to those in the KFS (first column). About 50 percent of the firms have one owner, slightly more than 30 percent have two owners, and about 7.5 percent have three owners. The similarity between the data in KFS and SSBF regarding the share of firms with approximately equally distributed ownership is even more striking. For example, for twoowner businesses, those shares are 71 percent for the KFS and 70 percent for the SSBF.

Finally, the last column of Table 2 describes small businesses in the CAF. Although this dataset is very different from the previous two, the fractions of firms with one, two, or three owners are similar to those in the KFS and SSBF. The key message is that although the firms in the three datasets differ, the distribution of firms by number of owners is strikingly similar.

The findings presented in Table 2 are replicated in other studies. For instance, Vereshchagina (2013) documents very similar patterns using the KFS. Interestingly, as noted earlier, Encinosa, Gaynor, and Rebitzer (2007) use a more specific dataset on medical practices and report that the fraction of practices with equal shares falls from 54.2 percent in practices with three to five physicians, to 42 percent in practices with six to seven physicians, to roughly 20 to 30 percent on average for larger practices.

\subsection{The Equal Distribution of Ownership Shares}

Using the KFS, we study ownership distribution in more detail. First, Figure 1 shows the distribution of businesses by number of owners. As described in Table 2, the fraction of firms decreases steeply with the number of owners, and most of the partnerships have three or fewer owners.

Next, we define the junior partner as the owner with the smallest share (i.e., less or equal to $100 / N$ percent, where $N$ is the number of owners). Figures 2 and 3 show the distribution of ownership shares for the junior partner conditional on two-owner and three-owner partnerships, respectively. In many of these businesses, the junior partner shares are close to the upper bound of equal distribution (i.e., 50 and 33 percent, respectively). That is, the shares are close to equally distributed.

\section{DYNAMICS OF THE OWNERSHIP STRUCTURE}

The second prediction in EKS (2014) is that, under private information, ownership shares change more frequently when firm ownership is unequally distributed. This change occurs because equally owned partnerships may not need to change the ownership structure to provide the incentive not to cheat. Hence, if private information is actually the reason for the 


\section{Figure 1}

\section{Distribution of Businesses by Number of Owners}

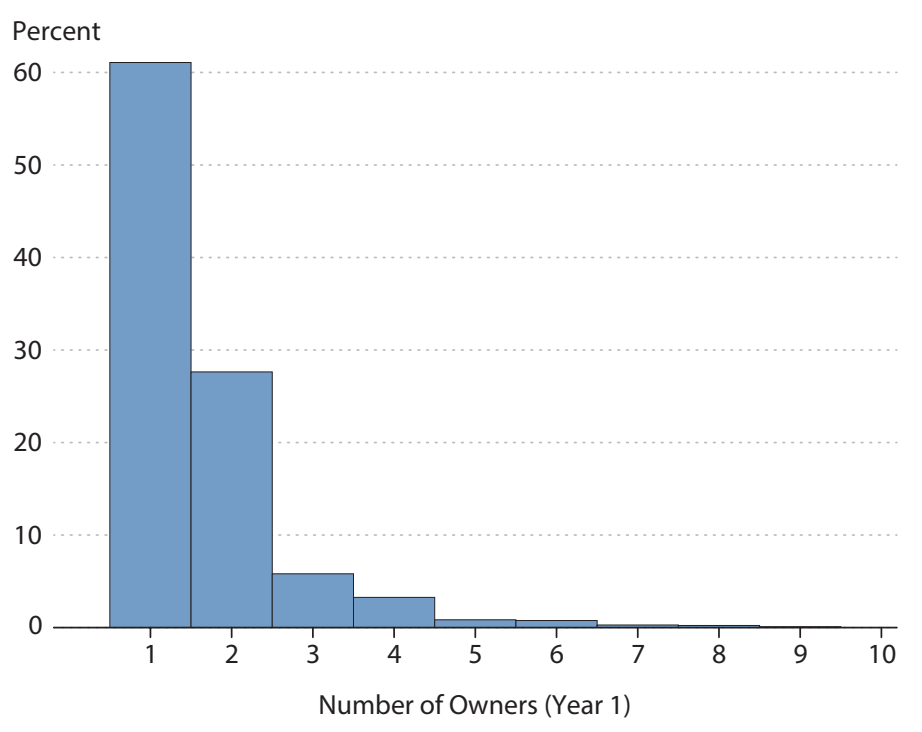

SOURCE: KFS

high occurrence of equally distributed ownership documented in Section 4, we should observe different ownership dynamics for those partnerships. Since the observed fluctuations in ownership shares may occur for reasons not included in the EKS model, the emphasis here is not on ownership changes per se but on the differences between changes in ownership shares among partnerships with varying ownership structures (equal vs. unequal).

Using the KFS, we compute the change in the ownership share of one of the partners over consecutive years. The results are striking. Figure 4 shows that although 88 percent of two-year-old partnerships started with equally distributed ownership and did not change ownership structure (right panel), only 39 percent of those that started with an unequally distributed ownership structure remained unchanged (left panel). These findings suggest that the current ownership structure is indeed an important determinant of the frequency of changes in ownership structure. EKS (2014) provide a rationale for this finding. They argue that if all owners have a sufficiently large share in the partnership, which is more likely if shares are approximately equally distributed, fluctuations in ownership shares may not be required to discourage cheating.

Another possibility is that there are observable differences between equal and unequal partnerships that may account for the dissimilarity in the dynamics of the ownership structure. To test whether observable differences can account for this dissimilarity, Table 3 uses the KFS to study the percentage of partnerships with an unchanged ownership structure across different characteristics, such as firm age, number of owners, legal status, profitability, and the number of employees. Indeed, Table 3 shows that observable differences between equal and unequal partnerships cannot account for the dissimilarity in the dynamics of the ownership structure. 
Espino, Kozlowski, Sánchez

Figure 2

Distribution of Junior Partner Ownership Shares, Two-Owner Businesses

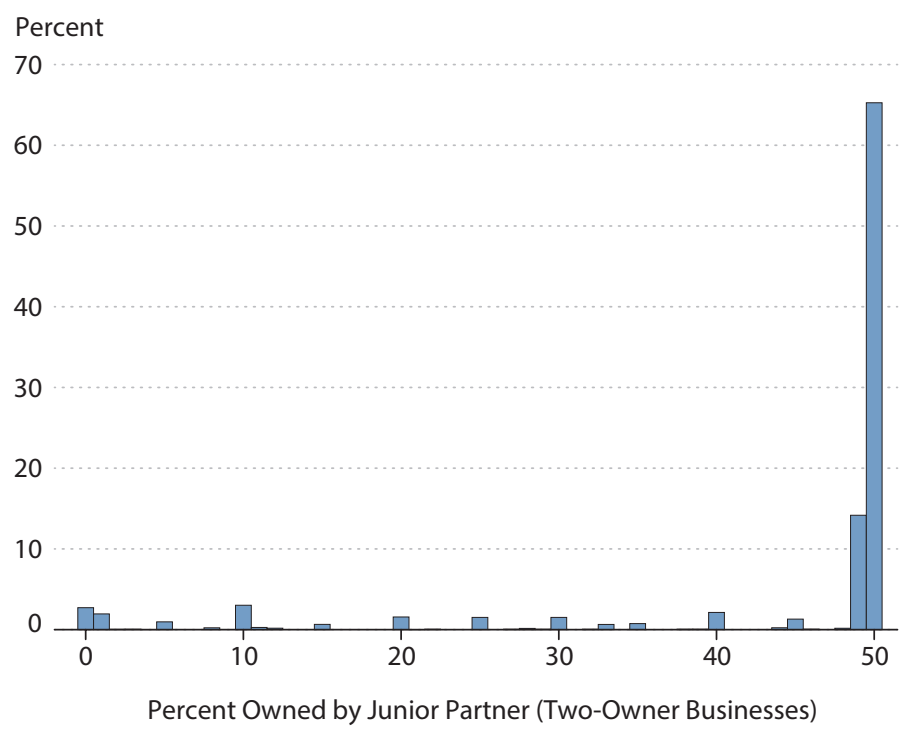

SOURCE: KFS

Figure 3

Distribution of Junior Partner Ownership Shares, Three-Owner Businesses

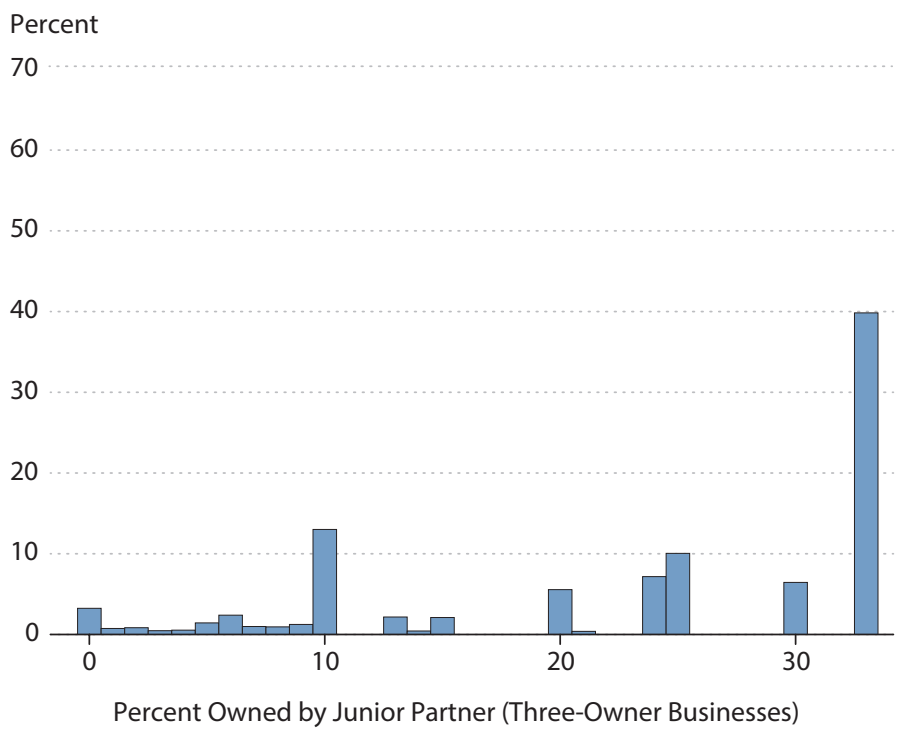

SOURCE: KFS. 


\section{Figure 4}

\section{Distribution of Changes in Junior Partner Ownership Shares by Ownership Structure}

2-Owner Firms

Unequally Distributed Shares Equally Distributed Shares

Percent

100

50

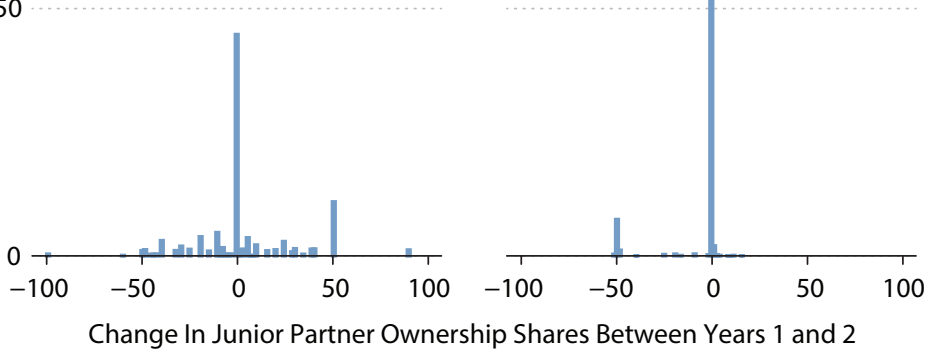

SOURCE: KFS.

Table 3

Percentage of Partnerships with an Unchanged Ownership Structure

\begin{tabular}{|c|c|c|c|c|c|c|}
\hline & \multicolumn{2}{|c|}{ Firm age: 2 years } & \multicolumn{2}{|c|}{ Firm age: 3 years } & \multicolumn{2}{|c|}{ Firm age: 4 years } \\
\hline & Equal & Unequal & Equal & Unequal & Equal & Unequal \\
\hline All & 87.9 & 38.8 & 90.0 & 45.1 & 94.7 & 53.3 \\
\hline 2 Owners & 89.2 & 43.7 & 92.5 & 53.2 & 96.6 & 56.3 \\
\hline 3 Owners & 96.1 & 62.7 & 95.6 & 65.3 & 92.5 & 70.8 \\
\hline General or limited partnership & 88.6 & 20.5 & 91.7 & 36.2 & 96.7 & 49.9 \\
\hline Other legal status & 87.8 & 44.8 & 89.7 & 52.8 & 94.4 & 60.1 \\
\hline Profitable & 86.7 & 46.4 & 90.5 & 57.1 & 97.1 & 60.2 \\
\hline Not profitable & 89.2 & 40.3 & 89.8 & 46.5 & 91.1 & 59.1 \\
\hline Increased employment & 87.7 & 48.6 & 92.6 & 46.9 & 96.6 & 59.9 \\
\hline Decreased employment & 88.1 & 34.2 & 89.8 & 45.3 & 94.5 & 51.1 \\
\hline Less than 5 employees & 87.0 & 39.1 & 90.1 & 47.4 & 94.6 & 60.0 \\
\hline More than 5 employees & 91.7 & 38.3 & 89.6 & 41.8 & 94.9 & 42.5 \\
\hline
\end{tabular}

NOTE: Equal, equal business ownership. Unequal, unequal business ownership. Decreased (increased) employment means that the number of employees in the firm decreased (increased).

SOURCE: KFS. 


\section{Table 4}

Probability of a Change in Ownership Shares and Ownership Structure

\begin{tabular}{lcccc} 
& \multicolumn{4}{c}{ Specification } \\
\cline { 2 - 5 } & $(1)$ & $(2)$ & $(3)$ & $(4)$ \\
\hline Equally owned & $-0.707^{* * *}$ & $-0.637^{* * *}$ & $-0.510^{* * *}$ & $-0.457^{* * *}$ \\
\hline Other controls & Yes & Yes & Yes & Yes \\
\hline Number of owners & 2 & $2-3$ & 2 & $2-3$ \\
\hline Type of firms & Partnerships & Partnerships & All & All \\
\hline$R^{2}$ & 0.56 & 0.48 & 0.31 & 0.27 \\
\hline Observations & 82 & 92 & 671 & 781
\end{tabular}

NOTE: Other controls are dummies for firm size and changes in profitability and the number of employees. ${ }^{* * *}$ indicates significance at the 1 percent level.

SOURCE: KFS.

In order to study the robustness of this finding, we estimate the following regression:

$$
\text { CHANGE }_{i}=\beta_{0}+\beta_{1} T_{B T C}+\beta_{2} X_{i}+\varepsilon_{i}
$$

where $C H A N G E_{i}$ is a dummy variable that takes the value 1 if the share of one partner changes and 0 otherwise; $T B T C_{i}$ is a dummy variable that takes the value 1 if the partnership is "equally owned" (i.e., in the too-big-to-cheat region) and 0 otherwise; and $X_{i}$ are different characteristics of the partnership used as controls. We are interested in the sign of $\beta_{1}$. A negative value implies that an equally distributed partnership decreases the probability of changing ownership shares.

Table 4 shows the results of estimating equation (1) as a linear probability model. $\underline{2}$ The different columns show alternative subsamples. The differences between the dynamics of partnerships with equally and unequally distributed ownership structures are robust. In column (1), the sample is restricted to two-owner partnerships. The coefficient in "equally owned" implies a 70-percentage-point lower probability of an equally owned partnership changing to an unequally owned partnership. As shown in columns (3) and (4), the results are similar, although slightly smaller, for all start-ups with two or three owners, that is, not only firms legally classified as partnerships.

\section{A ROLE FOR PRIVATE INFORMATION?}

In this section we study more directly the role of private information in predicting the features described above. First, we compare private family-owned and non-family-owned firms, arguing that family firms may be subject to less private information. Then, we compare partnerships in different countries and use an index of corporate transparency to measure the degree of private information in which firms operate. 


\subsection{Convergence to an Equally Owned Partnership}

The third prediction in EKS (2014) is that, under private information, the distribution of ownership shares moves toward either equal distribution of ownership or sole proprietorship. In contrast, under full information, ownership shares remain at the initial values. To test this prediction, we study how firms achieve equal ownership by taking advantage of the fact that family ties often serve as a second-best solution to the problem of private information. ${ }^{3} \mathrm{We}$ compare how the fraction of firms with ownership in the too-big-to-cheat region (i.e., with all ownership shares around $1 / N$, where $N$ is the number of owners) changes with firm age. The theory predicts this faction will increase more for privately owned firms.

Using the SSBF, we estimate the probability of the firm ownership structure being in the too-big to-cheat region and look at a cross section of firms to see how this probability changes with firm age and between private non-family-owned and family-owned firms. $\frac{4}{}$ In this section, we redefine the too-big-to-cheat region as all three owners having shares between $0.33 \times 0.975$ and $0.33 \times 1.025$, which is stricter than our previous definition of equal shares. $\underline{5}$

To test these theoretical predictions, we address two questions. First, how does the probability of having equally distributed ownership change with age? Second, do family-owned firms behave differently from private non-family-owned firms? We estimate the probability using the following regression:

$$
\mathrm{TBTC}_{i}+\beta_{0}+\beta_{1} \mathrm{Age}_{i}+\beta_{2} \mathrm{Age}_{i} \times \mathrm{PRIVATE}_{i}+\beta_{3} X_{i}+\varepsilon_{i},
$$

where PRIVATE $i$ is a dummy variable that takes the value 1 if the firm is private non-family owned and 0 if it is family owned. The theory predicts that $\beta_{2}$ should be positive. That is, the probability of being in the too-big-to-cheat region increases with age more for private nonfamily-owned firms than for family-owned firms.

Column (1) of Table 5 shows the estimation of equation (2) for three-owner partnerships. While the probability of being in the too-big-to-cheat region decreases slightly with age for family-owned firms, it increases significantly for private non-family-owned firms. The difference is exactly what the EKS theory predicts. Under private information, firms converge over time to the ownership structure that correctly aligns incentives. As column (2) shows, the results are similar for three- and four-owner firms. The results in columns (3) and (4) reproduce the regression including all firms, not only firms legally classified as partnerships. Although the coefficients are smaller, they are significant and have the same sign.

\subsection{Cross-Country Evidence}

The fourth prediction from EKS (2014) is that, if the information problems are more severe, the number of owners tends to decline more rapidly with age. To test this prediction we compare partnerships in different countries. Poorer countries have less corporate transparency and worse monitoring technologies. In fact, in the index of corporate transparency (CIFAR) constructed by Bushman, Piotroski, and Smith (2004), the lowest value is for Brazil (about 50) and the highest is for the United Kingdom (about 80). We combine the data from Bushman, Piotroski, and Smith (2004) with the CAF. As noted, the CAF survey interviewed 
Table 5

Firm Probability of Equally Shared Ownership by Firm Age and Type

\begin{tabular}{lcccc} 
& \multicolumn{4}{c}{ Specification } \\
\cline { 2 - 5 } & $(1)$ & $(2)$ & $(3)$ & (4) \\
\hline Firm Age x private firm & $0.0353^{* * *}$ & $0.0145^{* *}$ & $0.0112^{* * *}$ & $0.0073^{* * *}$ \\
\hline Firm Age & -0.0216 & 0.0019 & $-0.0113^{* * *}$ & $-0.0049^{* * *}$ \\
\hline Other controls & Yes & Yes & Yes & Yes \\
\hline Number of owners & 3 & $3-4$ & 3 & $3-4$ \\
\hline Type of firms & Partnerships & Partnerships & All & All \\
\hline$R^{2}$ & 0.16 & 0.15 & 0.08 & 0.04 \\
\hline Observations & 165 & 315 & 895 & 1,602 \\
\hline
\end{tabular}

NOTE: Other controls are owner race, gender, and education. ${ }^{* *}$ and ${ }^{* * *}$ indicate significance at the 1 percent and 5 percent levels, respectively.

SOURCE: SSBF.

households in several countries in Latin America and in the United States. A subset of those households reported that they owned a business and were asked a few questions. In particular, they were asked the number of owners and the age of the business. The average number of owners is 1.6, and the average age of the business is rather young, 3.3 years. We use these data to compare how the number of owners in the partnership changes with corporate transparency. In particular, we study whether private information exacerbates the convergence of partnerships to sole proprietorships.

To isolate the effect of private information on the change in the number of owners, we regress the number of owners on (i) firm age and (ii) the interaction between firm age and the CIFAR; that is,

$$
N_{i}=\beta_{0}+\beta_{1} A G E_{i}+\beta_{2} A G E_{i} \times C I F A R_{i}+\varepsilon_{i}
$$

where $N_{i}$ is the number of owners. The theory predicts that $\beta_{2}$ will be positive; that is, as corporate transparency increases, we should observe that the number of owners decreases less with firm age.

Table 6 presents the estimation of equation (3). The results in column (1) imply that in Brazil the number of owners decreases by 0.15 owners each year (i.e., $0.007 \times 50-0.5 \sim-0.15$ ), while in the United States the number of owners is approximately constant across firm age (i.e., $0.007 \times 70-0.5 \sim 0$ ). The other three columns confirm the results. In particular, columns (2) and (4) show that the results are not due to businesses with many owners-restricting the number of owners to less than four does not change the results. In addition, the results do not depend on outliers, since the results are very similar if we consider median regressions instead of ordinary least squares, as shown in column (3). 
Table 6

Number of Owners, Firm Age, and Transparency

\begin{tabular}{lcccc} 
& \multicolumn{4}{c}{ Specification } \\
\cline { 2 - 5 } & $(1)$ & $(2)$ & $(3)$ & $(4)$ \\
\hline Firm Age x CIFAR & $0.007^{* * *}$ & $0.006^{* * *}$ & $0.010^{* * *}$ & $0.011^{* * *}$ \\
\hline Firm Age & $-0.502^{* * *}$ & $-0.448^{* * *}$ & $-0.760^{* * *}$ & $-0.844^{* * *}$ \\
\hline Number of owners & All & $<4$ & All & $<4$ \\
\hline Type of regression & OLS & OLS & Median & Median \\
\hline$R^{2}$ & 0.06 & 0.06 & 0.1 & 0.10 \\
\hline Observations & 149 & 143 & 149 & 143 \\
\hline & & & \\
NOTE: OLS, ordinary least squares. ${ }^{* * *}$ indicates significance at the 1 percent level. \\
SOURCE: CAF.
\end{tabular}

\section{CONCLUSION}

We study the stylized facts on the organization of partnerships and compare the findings with a theory in which owners have private information about their liquidity needs (EKS, 2014). Misreporting liquidity needs (cheating) hurts the partnership because it distorts investment decisions, which implies that partners with sufficiently large ownership shares do not have an incentive to cheat. The best way to give a large share to each partner is to have only a few partners with equal shares. Indeed, we show that, in the data, most start-ups have two or three owners and usually start with equally distributed ownership shares. As the number of owners increases, however, the share each partner owns decreases, exacerbating the problem of private information. In fact, an equally distributed ownership structure is less common in partnerships with more owners. If one of the partners has an incentive to cheat, for instance, because his ownership share is too small, the optimal contract prescribes decreasing that owner's shares to provide the incentive not to cheat. In the data, we find that partnerships with equally distributed shares, which according to the theory would be less affected by private information, changed their ownership structure less frequently than those with unequally distributed shares. In addition, family-owned firms and firms in countries with better corporate transparency behave more like firms that operate under full information than private nonfamily-owned firms and firms in countries with less corporate transparency, which behave more like firms that operate under private information. Overall, the findings suggest that private information may be important for shaping the organization of small business partnerships. 


\section{Espino, Kozlowski, Sánchez}

\section{NOTES}

1 For example, while Microsoft was still a private company, cofounder Paul Allen was diagnosed with Hodgkin's lymphoma, which caused him to quit the company, leaving Bill Gates as the sole active founder during the crucial three years before the company went public (Wikipedia, 2016).

$\underline{2}$ The results of probit and logit models are similar and not included.

3 See, for instance, Bertrand and Schoar (2006). This fact has been used by Caselli and Gennaioli (2013) to explain why poor countries, with poorer monitoring and enforcement technologies, rely much more heavily on dynastic family-owned firms.

4 Since most of the two-owner firms in the survey have approximately equally distributed shares, we drop them and consider only three-owner firms.

$\underline{5}$ Changing the boundary of the too-big-to-cheat region from $[0.33 \times 0.975,0.33 \times 1.025]$ to $[0.33 \times 0.95,0.33 \times 1.05]$ does not to change the results.

\section{REFERENCES}

Bertrand, Marianne and Schoar, Antoinette. "The Role of Family in Family Firms." Journal of Economic Perspectives, Spring 2006, 20(2), pp. 73-96; http://dx.doi.org/10.1257/jep.20.2.73.

Bolton, Patrick and Von Thadden, Ernst-Ludwig. "Blocks, Liquidity, and Corporate Control." Journal of Finance, February 1998, 53(1), pp. 1-25; http://dx.doi.org/10.1111/0022-1082.15240.

Bushman, Robert M.; Piotroski, Joseph D. and Smith, Abbie J. "What Determines Corporate Transparency?" Journal of Accounting Research, May 2004, 42(2), pp. 207-52; http://dx.doi.org/10.1111/j.1475-679X.2004.00136.x.

Butters, John Keith and Lintner, John Virgil. "Effect of Federal Taxes on Growing Enterprises." Division of Research, Graduate School of Business Administration, Harvard University, 1945.

Carpenter, Robert E. and Petersen, Bruce C. "Is the Growth of Small Firms Constrained by Internal Finance?" Review of Economics and Statistics, May 2002, 84(2), pp. 298-309; http://dx.doi.org/10.1162/003465302317411541.

Caselli, Francesco and Gennaioli, Nicola. “Dynastic Management." Economic Inquiry, January 2013, 51(1), pp. 971-96; ISSN 1465-7295.

Encinosa, William E. III; Gaynor, Martin and Rebitzer James B. "The Sociology of Groups and the Economics of Incentives: Theory and Evidence on Compensation Systems." Journal of Economic Behavior \& Organization, February 2007, 62(2), pp. 187-214; http://dx.doi.org/10.1016/j.jebo.2006.01.001.

Espino, Emilio; Kozlowski, Julian and Sánchez, Juan M. "Too Big to Cheat: Efficiency and Investment in Partnerships." Working Paper 2013-001C, Federal Reserve Bank of St. Louis, 2014; https://research.stlouisfed.org/wp/more/2013-001.

Gaynor, Martin, and Gertler, Paul J. "Moral Hazard and Risk Spreading in Partnerships." RAND Journal of Economics, Winter 1995, 26(4), pp. 591-613; http://dx.doi.org/10.2307/2556008.

Hubbard, R. Glenn. "Capital-Market Imperfections and Investment." Journal of Economic Literature, March 1998, 36(1), pp. 193-225.

Kaya, Ayca and Vereshchagina, Galina. "Partnerships versus Corporations: Moral Hazard, Sorting, and Ownership Structure." American Economic Review, January 2014, 104(1), pp. 291-307; http://dx.doi.org/10.1257/aer.104.1.291.

Lang, Kevin and Gordon, Peter-John. "Partnerships as Insurance Devices: Theory and Evidence." RAND Journal of Economics, Winter 1995, 26(4), pp. 614-29; http://dx.doi.org/10.2307/2556009.

Levin, Honathan and Tadelis, Steven. "Profit Sharing and the Role of Professional Partnerships." Quarterly Journal of Economics, February 2005, 120(1), pp. 131-71; http://dx.doi.org/10.1162/qjec.2005.120.1.131.

Vereshchagina, Galina. "The Role of Individual Financial Contributions in the Formation of Entrepreneurial Teams." Working paper, Arizona State University, September 2013.

Wikipedia. "Paul Allen.” https://en.wikipedia.org/wiki/Paul_Allen, accessed August 24, 2016. 